\title{
Texture and Chemistry of Ilmenite, Catoca Kimberlite (Angola)
}

\author{
S. Robles ${ }^{1}$, M. Watangua ${ }^{2}$, L. Isidoro ${ }^{2}$, J. Melgarejo ${ }^{1}$, S. Galí ${ }^{1}$ and A. Olimpio ${ }^{3}$ \\ ${ }^{l}$ Dept. de Cristal-lografia, Mineralogia i Dipòsits Minerals, Facultat de Geologia, Universitat de \\ Barcelona, Catalonia, Spain \\ ${ }^{2}$ ENDIAMA, Luanda, Angola \\ ${ }^{3}$ Dept. de Geologia, Faculdade de Ciências, Universidade Agostinho Neto, Luanda, Angola
}

\begin{abstract}
The Catoca kimberlite, Lunda Sul province, is the most important primary diamond deposit in Angola. This kimberlite is hosted by Precambrian rocks and covered by Mesozoic sedimentary deposits. This study presents results of the initial phase of the research project, "Kimberlites associated to the Lucapa structure, Angola (Africa)", within the framework of a multilateral agreement between the Faculty of Geology-Universitat de Barcelona, the Empresa Nacional de Diamantes de Angola and the Agostinho Neto University (Luanda-Angola). The research is based on two sets of core sampling down to $600 \mathrm{~m}$ deep. The first set comes from Catoca pipe and allowed us to identify complete crater and diatreme facies. The second one (18 kimberlites) comes from Cucumbi, Cacuilo, Tchiuzo, Alto Cuilo, Camitongo and Kambundu, whose samples were gathered during fall 2008. Currently, we are working on these sets of samples.
\end{abstract}

\section{Regional setting}

The area of interest is localized in northeastern Angola, Africa (Fig. 1), being tectonically controlled by the Lucapa structure, a former rift (Guiraud et al., 2005) of early Cretaceous that extends NE-SW across Angola. Associated to this structure there is a magmatic belt, which is composed by kimberlites toward $\mathrm{NE}$ and carbonatites toward SW. At present, over 2000 kimberlites have been identified in this structure and their diamond potential is currently being studied. The Catoca kimberlite is the most important primary diamond deposit in Angola, hosted by Precambrian rocks and covered by Mesozoic-Cenozoic sedimentary deposits (Janse and Sheahan, 1995).

\section{Petrography}

There are some minerals inside kimberlites which are frequently associated to diamond and they are used as indicator minerals in diamond exploration. The main indicator minerals are: magnesian ilmenite (Pell, 1998), garnet and chromite (Wyatt et al., 2004). However, for this instance we will focus on ilmenite since it is the first mineral analyzed in 2007.

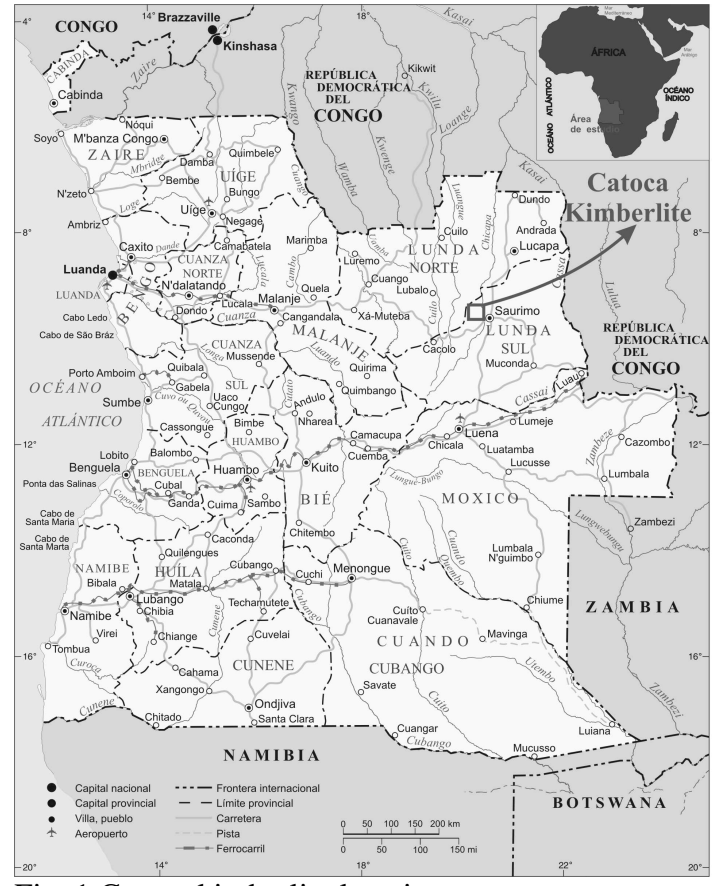

Fig. 1 Catoca kimberlite location

Diverse xenoliths, comprising lherzolite, eclogite, harzburgite, carbonatite, gneiss and amphibolite are distributed through the Catoca and Cucumbi kimberlites. Some shales and sandstones can be present in the upper part of this Kimberlite. Accessory minerals and xenocrysts comprise garnet, zircon, Cr-rich diopside, amphibole, phlogopite, chromite and several generations of ilmenite. Secondary minerals include serpentine-group minerals being the most abundant, calcite, barite, barytocalcite, witherite and strontianite.

Thin sections were observed through optical petrographic microscope and Scanning Electron Microscope-Environmental Scanning Electron Microscope (SEM-ESEM). This electron microscopy study with Back Scattered Electrons (BSE) images and Energy Dispersive Spectroscopy (EDS) microanalysis 
allowed us to discriminate up to six textural types of ilmenite in Catoca and Cucumbi kimberlite: a) intercumular ilmenite in peridotitic xenoliths (Fig. 2); b) anhedral ilmenite in carbonatite xenoliths; c) ilmenite unaltered megacrysts; d) nodular xenocryst of ilmenite with different grades of replacement, some of them with symplectitic textures (Fig. 3); e) skeletal ilmenite; and f) euhedral crystals of ilmenite in matrix (Fig. 4).

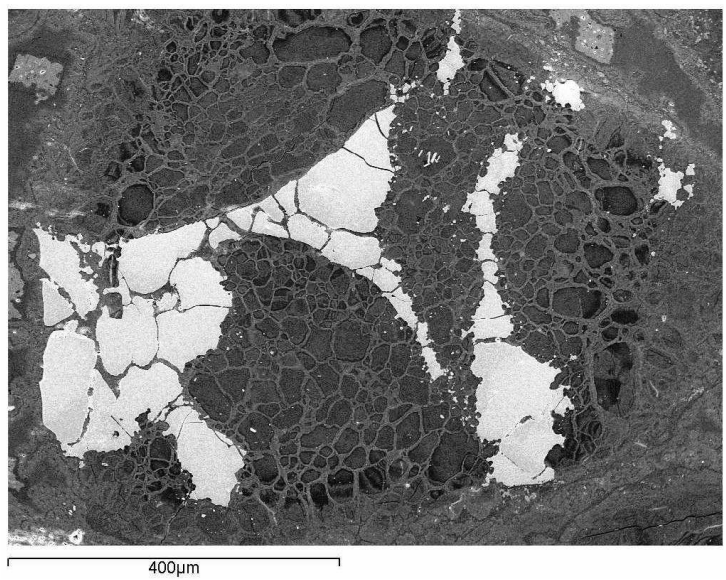

Fig. 2 Intercumular ilmenite in peridotitic xenolith

Zircon xenocrysts are partially replaced by fine-grained baddeleyite, and at least two populations exist according to the trace element distribution. All of these crystals are enriched in HREE, but with a noticeable positive Ce anomaly, similar to that reported in zircon in a MARID xenolith from a southern African kimberlite (Dawson et al., 2001). The crystals are not optically zoned, but there is a slight depletion in REE from the core to the rim.

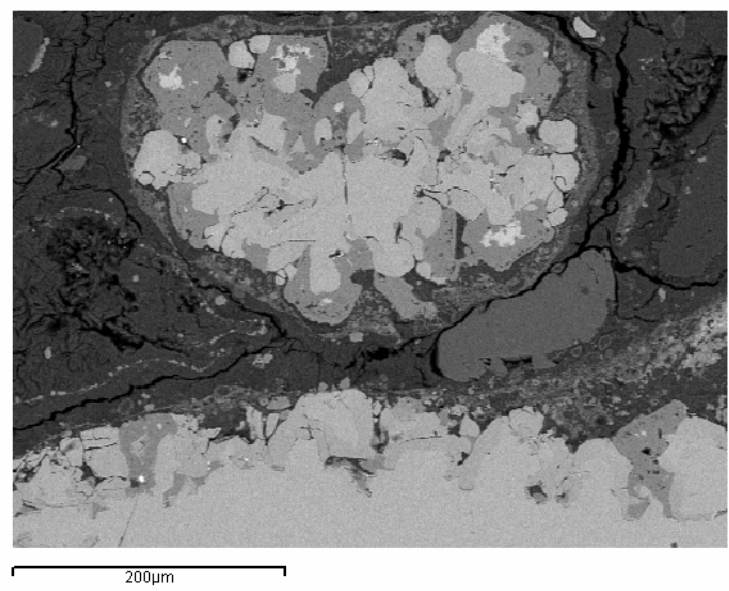

Fig. 3 Nodular xenocrysts of ilmenite with replacement

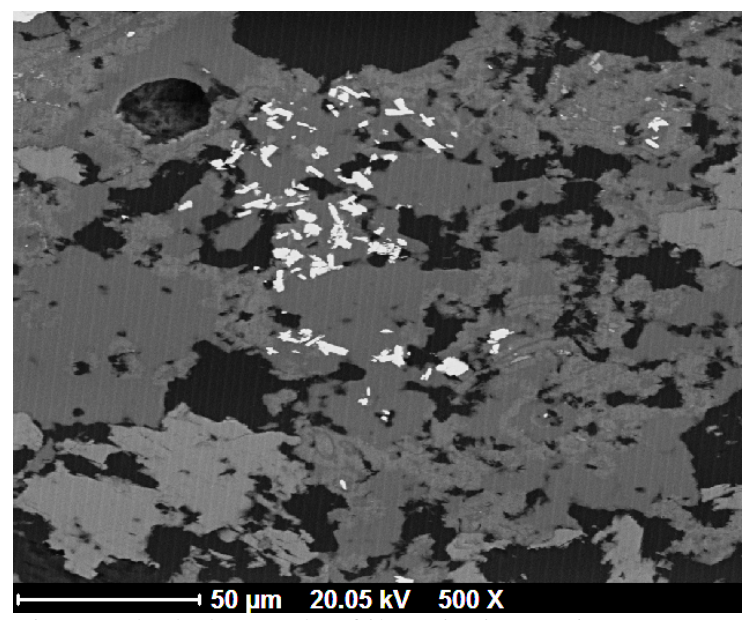

Fig. 4 Euhedral crystals of ilmenite in matrix

\section{Mineral chemistry of ilmenite}

Every texture has been systematically examined with Electron Probe Micro Analyzer (EPMA) which allowed us to identify three compositional types of ilmenite (I, II and III). This combined technique texture and composition analysis- has been suitable for analyzing zircon and garnet as well.

The primary ilmenite (type I) in megacrysts (xenocrysts) is generally rich in $\mathrm{Cr}$ and $\mathrm{Fe}^{3+}$. Its composition is similar to the intercumulus crystals in peridotite xenoliths. This ilmenite is replaced, in the first instance, by magnesian ilmenite (type II). This process takes place along microdiscontinuities (cleavage, border grains, contour subgranes, kink band planes, etc.), producing diffusive replacements. In a more advanced stage, symplectitic replacements occur, involving an early generation of magnesian ilmenite (type II) at the expense of $\mathrm{Fe}^{3+}$-rich primary ilmenite (from texture a to $\mathrm{d}$ ). A late generation of $\mathrm{Mn}-\mathrm{Nb}-\mathrm{Zr}$ rich ilmenite (type III) cuts the previous ones.

Contrastingly, the late euhedral $\mathrm{Mn}-\mathrm{Nb}-\mathrm{Zr}$ ilmenite crystals found in the kimberlite matrix do not present any evidence of replacement. This ilmenite is poor in $\mathrm{Mg}$ and $\mathrm{Fe}^{3+}$. Their compositions are identical with the Mn-rich ilmenite produced during late replacement stages of ilmenite megacrysts. Compositions of $\mathrm{Mn}$ rich ilmenite are similar to those found in carbonatite xenoliths.

\section{Disscusion and conclusions}

Textural evidences indicate a different complex history of growth in the xenocrysts. Unaltered megacryst ilmenite (ilmenite type I) rich in $\mathrm{Fe}^{3+}$ (Fig. 5), indicates crystallization under high $\mathrm{fO}_{2}$ conditions; this ilmenite contains $\mathrm{Nb}, \mathrm{Cr}, \mathrm{Ni}$ and $\mathrm{Ta}$ in low contents. Its composition is similar to those ilmenite Intercumular megacrysts that occur in peridotite xenoliths. Hence, most of the ilmenite xenocrysts seem to have been 
produced by disaggregation of mantle xenoliths. Ilmenite $\mathrm{I}$ is replaced along discontinuities by magnesian ilmenite (ilmenite type II); the elemental distribution of $\mathrm{Mg}$ in these grains points to processes of replacement through solid-state diffusion in a typical reducing environment. Magnesian ilmenite is also enriched in $\mathrm{Cr}$ and $\mathrm{Ni}$. More advanced replacement produces a symplectitic replacement of ilmenite II by ilmenite III.

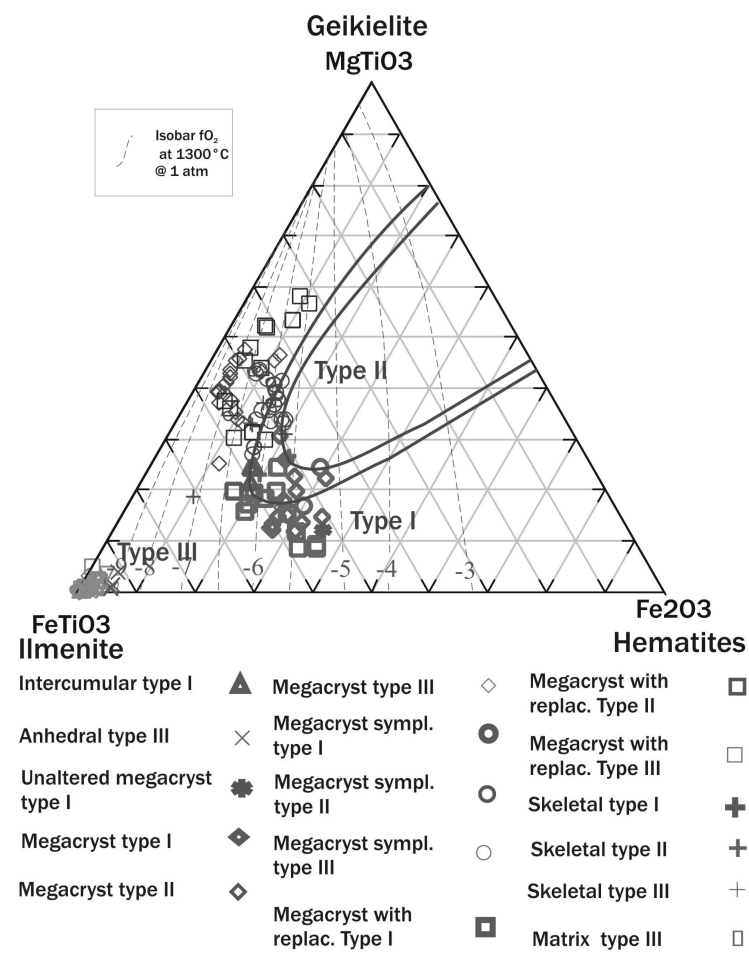

Fig. $5 \mathrm{MgTiO}_{3}-\mathrm{FeTiO}_{3}-\mathrm{Fe}_{2} \mathrm{O}_{3}$ ratio for the different types of ilmenite (I, II and III) discriminated for each texture.

A late generation of ilmenite III (Mn-rich ilmenite) is found rimming all the above mentioned generations, and is strongly enriched in $\mathrm{Nb}, \mathrm{Ta}, \mathrm{Zr}, \mathrm{W}, \mathrm{Hf}$, Th and $\mathrm{U}$, and poor in $\mathrm{Mg}$ and $\mathrm{Fe}^{3+}$. The composition of this ilmenite is similar to that of the fine-grained euhedral ilmenite crystals found in the kimberlitic matrix and also to that of the ilmenite crystals found in the carbonatitic xenoliths. Crystals of Mn-rich ilmenite (ilmenite type III) are not replaced or zoned, and seem to have crystallized in equilibrium with the kimberlitic magma. Both the late generations of ilmenite and the baddeleyite replacing zircon can be produced by interaction of a carbonate-bearing kimberlitic magma enriched in Mn and HFSE. The replacement of $\mathrm{Fe}^{3+}$ rich ilmenite by $\mathrm{Mg}$ - and $\mathrm{Mn}$-rich ilmenite implies that the early ilmenite was formed under oxidizing conditions in the mantle, and the lastest compositions of ilmenite were produced by reaction with the kimberlitic magma.

Megacrysts of ilmenite are frequently present in diamondiferous kimberlites, contrasting with ilmenite observed in barren kimberlites. This might become a new guide in diamond exploration.

In conclusion, the composition of this ilmenite is the result of a set of replacement processes with rich fluids in $\mathrm{Mg}$ and $\mathrm{Mn}$ affecting an oxidized primary ilmenite in a higher or lower grade. These fluids are reducing, especially those rich in Mn. Picroilmenite has traditionally been interpreted as an indicator of kimberlite associations, as well as an indicator of low $\mathrm{fO}_{2}$, which is necessary for the preservation of diamond. Although Catoca and Cucumbi are diamondiferous kimberlites, they show that $\mathrm{Mg}$ ilmenite is clearly a late replacement product, and the grade of replacement of the primary grains is very variable. Therefore the absence of magnesian ilmenite in a kimberlite does not appear to be a convincing argument to exclude the presence of diamonds. Accordingly, this work proposes a new insight into the concept of ilmenite in diamond exploration.

\section{Acknowledgments}

This research is supported by the project CGL200612973 of Ministerio de Educación y Ciencia (Spain), the AGAUR SGR 589 of Generalitat de Catalunya and a FI grant sponsored by the Departament d'Educació i Universitats de la Generalitat de Catalunya i del Fons Social Europeu. The authors acknowledge the Serveis Cientificotècnics - Universitat de Barcelona.

\section{References}

Dawson, J.B., Hill, P.G., Kinny, P.D., 2001: Mineral chemistry of a zircon-bearing, composite, veined and metasomatised upper-mantle peridotite xenolith from kimberlite. Contributions to Mineralogy and Petrology, 140, 720-733.

Guiraud, R., Bosworth, W., Thierry, J., Delplanque, A., 2005: Phanerozoic geological evolution of Northern and Central Africa: An overview. Journal of African Earth Sciences, 43, 83-143.

Janse, A.J.A., Sheahan, P.A., 1995: Catalogue of world wide diamond and kimberlite occurrences: a selective and annotative approach. Journal of Geochemical Exploration, 53, 73-111.

Pell, J., 1998: Kimberlite-hosted Diamonds, in Geological Fieldwork 1997. British Columbia Ministry of Employment and Investment 1998-1, 24L1-24L4.

Wyatt, B.A., Mike, B., Anckar, E., Grutter, H., 2004: Compositional classification of "kimberlitic" and “non-kimberlitic" ilmenite. Lithos 77, 819-840. 